\title{
Everyday Conversions: Islam, Domestic Work, and South Asian Migrant Women in Kuwait
}

\author{
Attiya Ahmad \\ Durham, NC: Duke University Press, 2017. 288 pages.
}

There is a tendency in academic literature to compare and contrast religions to try to understand the motivations of the convert. What are the costs and benefits of conversion? What is gained and what is lost? Thinking in these utilitarian terms can lead to a focus on causality and materiality, rather than the metaphysical and ephemeral aspects of religious thought and practice. Furthermore, religious conversion to Islam is often mired in the same prejudices and stereotypes of the orient found in western and predominantly Judeo-Christian depictions of the Middle East, the region that Islam is most often associated with. In Everyday Conversions: Islam, Domestic Work, and South Asian Migrant Women in Kuwait, Attiya Ahmad moves away from the emphasis on what distinguishes religious traditions and discursive communities to focus on what religious conversion means to the individual convert. Ahmad seeks to counter the notion that conversion must have some material benefit to the convert and instead looks at the quotidian character of religious transformation. Ahmad argues in her ethnographic work that conversion can be understood through the minutiae of daily interactions, conversations, and affections that develop over time. She follows the lives of migrant domestic workers in the Gulf and their relationships with their employers as well as their own families over the course of their conversions and argues that it is neither the strength of the da'wa movement in Kuwait, nor the benefits gained by conversion to the employee/employer relationship that effectively describes the reason the women convert (although Ahmad is admittedly not looking for causality). Instead, Ahmad writes: "I have sought to tell a more modest and mundane set of stories that convey moments of slippage, tension and traces of feelings, thoughts and impressions of everyday conversion" (194).

The strengths of Ahmad's ethnography lie in its attention to detail and equanimity in representing the challenges of migration and domestic labor. Ahmad is careful not to create victims, nor inflate the value of the women's migration and conversion to their economic or personal well-being. In this approach, there are hints of Lila Abu-Lughod's and Saba Mahmood's work with women who appear to be in marginal or precarious positions. Like 
these feminist ethnographers, Ahmad is attuned to the ethics and politics of representation, but with an eye towards transnational and cultural studies. In its theoretical framing, the ethnography calls to mind the work of Michel DeCerteau in The Practice of Everyday Life, which rejects theories of production to focus on the consumer. Furthermore, by placing conversion in light of transnational migration, Ahmad also shows how the individual convert navigates her conversion through the complex nexus of Kuwait City as well as her own home town. Thus, the individual convert as artist of her own conversion is the primary subject of Ahmad's book. My one critique of the book would be in the area of theory, where Ahmad is hesitant to challenge others who have written on the subject of Islamic religious faith and practice, despite the theoretical weight evident in her ethnography.

In the introduction, Ahmad begins with Talal Asad and Saba Mahmood's seminal arguments in the field of anthropology of Islam, which she argues "relativize and provincialize secular modern understandings of subjectivity, agency and embodied practice" (9). She distinguishes her work from Asad and Mahmood's by utilizing a transnational feminist framework that highlights the process of "mutual constitution and self-constituting othering, as well as sociohistorical circumstances" (10). Ahmad wants to go beyond discursive narratives of secular liberalism and the Islamic piety movement. Specifically, Ahmad follows the approach of Eve Sedgewick, who eschews Judith Butler's "strong theory" in exchange for an approach that looks at factors that "lie alongside" gender performativity (23). Ahmad does this by showing "how religious conversion also constitutes a complex site of interrelation through which religious traditions are configured and reconfigured together" (24). Instead of showing conflict or contrasting discursive traditions, Ahmad contends that the best way to understand the lives and stories of her interlocutors are in the quotidian affairs of the households they work and live in. She divides the chapters into the affective experiences the women have as a result of their migration experiences, which in turn spur their conversions.

Chapters one and two cover the political and geographic terrain that the women must cut across, which produces an overwhelming feeling of being neither here nor there, but temporarily suspended between states, households, and religions. Chapter one paints a somewhat grim picture of the politically precarious position of migrant women within the kefala system, labor laws, and bans on migrations often creating impossible conditions for migrant woman. Chapter two sets out to "discern, document and describe" (66) the migratory experience and why it produces uncertainty 
about one's place in the world. It follows the women back and forth between Kuwait and their home countries, emphasizing the socio-historical context that requires a transnational feminist framework. The four women that Ahmad follows throughout the book share their migratory journeys and their sense of "suspension" between two households.

This chapter segues neatly into chapter three, where the women share how being a female migrant and domestic laborer requires knowledge of cross-cultural norms regarding gender, all of which require the women to be naram, "a gendered, learned capability of being malleable that indexes proper womanhood" (122). In their own eyes, a successful domestic worker from South Asia bends to the norms of the society they are in, and they attribute male and female migrant failure to being too sakht, or hard and unyielding. Here, I would have liked a stronger connection between how she describes naram and how Mahmood describes malaka. Does being naram lay the groundwork for women's conversion to Islam, a religion which requires the ability to engage in rituals entailing patience, modesty, and steadfastness? Ahmed hints at this connection in the conclusion to the chapter-"Being naram resonates with the fluid, flexible student-centered pedagogies of Kuwait's Islamic dawa movement, thus facilitating domestic worker's deepening learning of Islamic precepts and practices" (123) - but she could have spent more time discussing the overlap in the concepts in either chapter three or five, where she discusses the $d a^{\prime}$ wah movement.

Chapters four and five deal directly with questions of religious thought and practice and illustrate how the women grapple with Islamic practices in the household as their relationships with their employers deepen. Chapter five is about the household and the everyday conversations or "house talk" that Ahmad argues are the touchstones for the women's conversion. The daily relations in the household make blending and layering practices of Islam onto older traditions and rituals seem easy and natural. Ahmad argues that "the work undertaken by domestic workers-such as tending to family members during trips and caring for the elderly or the infirm-necessarily involves the disciplining and training of their comportment, affect and sense of self" (129) and makes Islamic practices easier to absorb as well. Chapter 6 is a foray into the da'wah movement classroom. Like Mahmood's Politics of Piety, Ahmad shows how the teachers and students use the space to create "intertwining stories" of patience in the face of hardship and the eventual rewards that come from this ethical re-fashioning, which mirror their own hardships as converts and help them deal with the dilemmas of being female migrant and domestic workers. The chapter ends with a 
sense of uncertainty, returning to the themes of temporality and suspension that began the book. Ahmad can't say whether the conversions will remain fixed pieces or will bend and move with the women as their circumstances change.

In the epilogue, Ahmad follows the "ongoing conversions" of her interlocutors as some of them return home as Muslims and encounter new challenges. As a book that focuses on the everyday, it is fitting to end on a new day and possibly, a new conversion. The strength of Ahmad's ethnography is in giving center-stage to the considerable creativity and diligence migrant women show in piecing together their own conversions. This piecing together is perfectly captured by the book's cover, which features Azra Aksamija's "Flocking Mosque". The structure of a flower illustrates how believers form a circular and geometric shape when gathered in devotion to God. Like Aksamija's patterns, which build into a circular design, Ahmad's chapters each represent a key piece of the story of migrant domestic workers' conversion to Islam as a gradual process that blends nations, households, and individuals together to create a narrative about the women's newfound faith. Scholars should read this book for its textured and detailed observations about migrant women's daily lives and for its treatment of religious conversion as a gradual process that unfolds in the everyday experiences of individuals. It would also be a great book for students as theory takes a back seat to the ethnography. The book is a refreshing, graceful approach to the subject of religious conversion and Islamic faith. Ahmad stays focused on telling her interlocutors' stories while navigating often conflicting positions.

Rehenuma Asmi Assistant Professor of Education and International Studies Allegheny College 